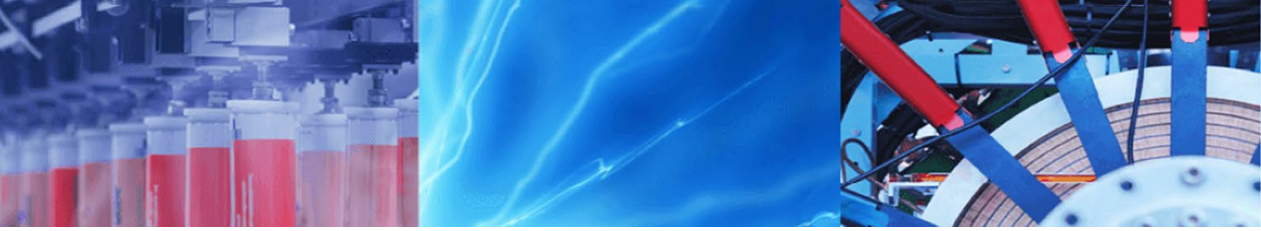

Research Article

\title{
Impact of sewage effluent discharges prediction using QUAL2Kw in a sensitive protected area: Portugal
}

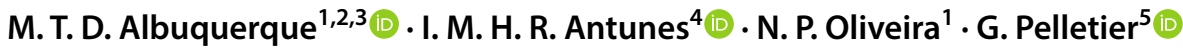

(c) Springer Nature Switzerland AG 2019

\begin{abstract}
The quality of water, under the influence of the wastewater treatment plant's discharges, makes the simulation of the water parameters a key issue, broadly when considering intermittent rivers. In the case of study, the Pracana reservoir works as an example of the characterization, monitoring and control of the impact of several wastewater treatment plants' discharges, directly contributing to water quality. Proença-a-Nova's wastewater treatment plant contributes directly to the Pracana reservoir (Central Portugal), which is a protected field. Twelve georeferenced water samples were gathered, between the sewage discharge and downstream to the Pracana reservoir, at almost equal distances. Sampling campaigns were taken during three different periods: rainy winter (January), intermediate conditions (March) and dry season (June). The following chemical parameters were analyzed: biochemical oxygen demand $\left(\mathrm{BOD}_{5}\right)$, dissolved oxygen (DO), dry residue, $\mathrm{P}_{\text {total }} \mathrm{N}_{\text {total, }} \mathrm{pH}$, temperature and microbiological parameters. $\mathrm{DO}, \mathrm{BOD}_{5}$ and microbiological parameters served as indicators for environmental pollution evaluation. A coupled hydrodynamic and water dispersion model, QUAL2kw, was used for water's quality simulation. The results lead to conclude that the water quality is acceptable for multiple purposes, except for human consumption, mainly due to moderate-to-high values of $\mathrm{BOD}_{5}$.
\end{abstract}

Keywords Water quality · Modeling $\cdot$ QUAL2Kw $\cdot$ Wastewater treatment plant $\cdot$ Pracana reservoir $\cdot$ Portugal

\section{Introduction}

Sewage discharge is one of the problems in developed and developing countries. It contributes to a compounded unstable aquatic ecosystem, including but not limited to oxygen demand and nutrient loading of the receiving watershed [1-4]. In addition, sewage effluent may be of public health significance, especially if effluent is discharged into water that is subsequently used for drinking, recreation or agricultural purposes $[5,6]$.

Watershed characteristics and stream inflows have been increasingly considered as factors affecting water quality in a variety of environments and different scales [7-11]. Water quality models are useful tools for determining contaminant plume behavior and impacts in water quality. Simulated scenarios are especially useful for accessing multiple possibilities and proactively developing response plans for rapid and appropriate actions if a contaminant event occurred [11-13].

Pollution simulation is a serious issue as it has consequences for hydrological modeling and discharge predictions for environmental impact assessment [14-17]. Modeling can be a useful management tool because models allow understanding the water body response to different pollution pressure scenarios which may assist in the decision-making process and in prosecuting the Water Framework Directive objectives. This study points to evaluate the usage of water quality models (QUAL2Kw) to

M. T. D. Albuquerque, teresal@ipcb.pt | ${ }^{1}$ Instituto Politécnico de Castelo Branco, Av. Pedro Álvares Cabral, n 12 , 6000-084 Castelo Branco, Portugal. ${ }^{2}$ CERNAS| QRural, Instituto Politécnico de Castelo Branco, Av. Pedro Álvares Cabral, n 12, 6000-084 Castelo Branco, Portugal. ${ }^{3} \mathrm{ICT} \mid$ Universidade de Évora, Largo dos Colegiais 2, 7000 Évora, Portugal. ${ }^{4}$ ICT/University of Minho, Campus de Gualtar, 4710-057 Braga, Portugal. ${ }^{5}$ Washington State Department of Ecology, Olympia, WA, USA.

SN Applied Sciences (2019) 1:1167 | https://doi.org/10.1007/s42452-019-1095-y 
better understand the response of a river under the influence of different loads of nutrients. QUAL2Kw was used to model water quality of the Pracana River (Portugal), a river contributing to a protected reservoir called Pracana which represents an important ecosystem to the local community.

Water is a natural resource whose availability depends on its quantity and quality. In freshwater's availability evaluation, it is pivotal to know the pollutant loads, topical and diffuse ones $[18,19]$. In the last decades, surface water contamination has drastically increased mainly due to anthropogenic emissions of nutrients. The European Union (EU) water legislation and the Water Framework Directive (WFD, 2000/60/EC) aim to achieve and maintain good chemical and ecological status of surface and groundwater. The European Water Framework Directive 2000/60/EC (WFD) refers to an integrated approach for eutrophication characterization and stresses the surface waters' trophic status assessment as a central goal of WFD objectives achievement. Environmental quality standards based on annual average and maximum allowable concentrations were defined for a priority group of substances (EU Watch List) that represent a significant risk for the aquatic environment and thereby human health (Directive 2013/39/EU). Subsequently, the EU Watch List was established on monitoring potentially harmful substances (Decision 2015/495/EC), and such are chemical and microbiological parameters. While an awareness regarding the occurrence and distribution of priority and emerging concern substances in EU catchments is developing [20,21], there is still a gap on the spreading of these contaminants in surface waters, including those restricted in the EU [21, 22]. Considering that the majority of the chemicals are originated from urban and agricultural areas and enter in the aquatic environment mainly via urban runoff [23], and/or domestic and industrial wastewaters [21], a special focus should be addressed toward domestic and agricultural catchments [24, 25].

Mathematical modeling allows the estimation of contamination loads into an aquatic environment [26-29], establishing cause-effect relations between pollution sources and water quality, as well as to simulate different response scenarios of the aquatic environment under different controlled situations. The simulation outputs work as a management tool for policy-makers predicting the effect of accidental discharges or additional pollutant loads. In the literature, several examples of QUAL2KW modeling can be found, used as a tool for simulating the water quality in rivers and catchment areas using as control parameters: biochemical oxygen demand $\left(\mathrm{BOD}_{5}\right)$ [30], nitrogen, phosphorus and chemical oxygen demand (COD) $[17,28,29,31]$ loads. QUAL2KW is also broadly used to study water quality management strategies $[26,28]$.
QUAL2Kw model was applied to model Pracana River's water quality, aiming for a straightforward representation of the complex parameters responsible for the overall water quality downstream of the river, under the influence of the Proença-a-Nova wastewater plant's discharges.

\section{Materials and methods}

The Ocreza River and its tributary the Pracana River are in Central Portugal and have their origin in an important Alpine Portuguese chain called Gardunha, included in the Tagus River watershed. The Pracana's waters have an important purpose by being abundantly used in agriculture. Proença-a-Nova wastewater treatment plant was dimensioned to serve 2234 inhabitants with a depuration ability of $326 \mathrm{~m}^{3} /$ day and discharges directly into the Freixada River, which runs straight to the Pracana River and, therefore, to the Pracana reservoir (Fig. 1). Characterization, monitoring and control of water quality, due to the several wastewater discharges, are of substantive importance.

Twelve georeferenced surface water samples were gathered between the sewage effluent discharge and its confluence with the Pracana reservoir (Fig. 2) during the year of 2010. Secondary inflows were identified and water samples collected downstream, at roughly equal lengths. The fitted model was calibrated using a subset of the collected samples (10-11).

The following physical-chemical parameters were analyzed: biochemical oxygen demand $\left(\mathrm{BOD}_{5}\right)$, chemical oxygen demand (COD), dissolved oxygen (DO), dry residue, total phosphorus $\left(\mathrm{P}_{\text {total }}\right)$, total nitrogen $\left(\mathrm{N}_{\text {total }}\right)$, $\mathrm{pH}$ and temperature. The microbiological parameters $\mathrm{DO}$ and $\mathrm{BOD}_{5}$ were used as water contamination indicators and, consequently, as key attributes in the subsequent modeling procedure. Temperature $\left(T,{ }^{\circ} \mathrm{C}\right), \mathrm{pH}$ (Sörensen scale), electrical conductivity $(E C, \mu \mathrm{S} / \mathrm{cm})$, dissolved oxygen (DO, $\mathrm{mg} / \mathrm{L})$, oxi-reduction potential (ORP), dry residue (ppm) and salinity $(\mathrm{mg} / \mathrm{L})$ were field measured using a multiparametric portable probe $\mathrm{HI} 9828$, Hanna Instruments. Biochemical oxygen demand $\left(\mathrm{BOD}_{5}\right)$, chemical oxygen demand (COD), dissolved oxygen (DO), dry residue, total phosphorus $\left(\mathrm{P}_{\text {total }}\right)$, total nitrogen $\left(\mathrm{N}_{\text {total }}\right)$ followed the protocol expressed in Table 1.

A water quality model was fitted using a coupled hydrodynamic and water dispersion model, the QUAL2kw, developed by the US Environmental Protection Agency (US EPA) [32]. QUAL2Kw is a one-dimensional and steady flow stream water quality model, implemented in Microsoft Excel, using a general equation of mass balance for the concentration of a constituent $c_{i}$ in the water column (excluding hyporheic exchange), in a reach i [32]. Microsoft 


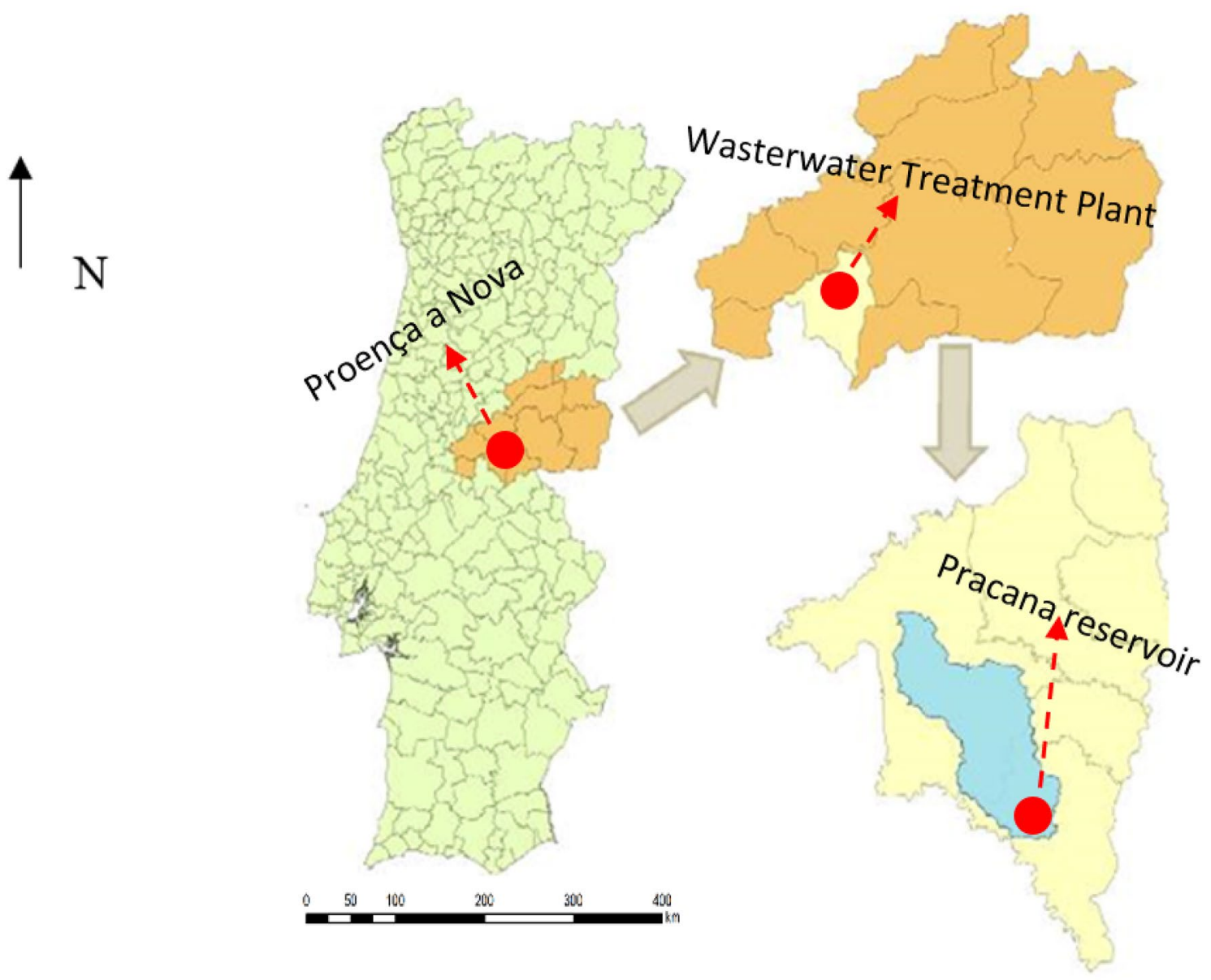

Fig. 1 Proença-a-Nova: a wastewater treatment plant; b Pracana reservoir

Excel is the graphical user interface for input, running and output layouts. The spatial approximation of one dimension (1D) has been considered appropriate for the study area as the river-reaches are long relative to the mixing length over the cross section and the transport of contaminants is dominated by longitudinal liquid motion [33]. The QUAL2Kw model represents a river as a series of reaches with constant hydraulic characteristics (e.g., slope, bottom width, etc.). The model simulates dendritic water systems, i.e., simulations extending not only to the mainstream, but likewise to its tributaries. The model is capable of simulating (1) the stream's main flow and three tributary streams. Tributaries can be operated independently or integrated into the main branch depending on user needs [34]. The Freixada River was segmented into nine sections of approximately $2.5 \mathrm{~km}$ each, assuming constant values for the side slope, bottom width and channel roughness (Figs. 2 and 3).

Sampling surface water campaigns were taken during 2010, in three different periods: (1) rainy winter (January); (2) intermediate conditions (March) and (3) dry season (June). Dissolved oxygen (DO), biochemical oxygen demand $\left(\mathrm{BOD}_{5}\right)$ and the microbiological parameters (MP) were used as organic matter indicators and as parameters for assessing environmental water contamination (Table 1).

\section{Results and discussion}

The analyzed surface water attributes went through a comparative statistic evaluation aiming to stress their spatiotemporal variability (Fig. 4). It is possible to identify the samples PR2 (discharge point) and PR3 as the ones with the highest $\mathrm{BOD}_{5}$ and highest microbiological parameter values and, consequently, the lowest DO content (Figs. 5 and 6). These parameters have a considerable decrease heading the river downstream, pointing out to a good self-depuration (Fig. 3). It is also worth noticing that during April (intermediate season), the highest values are observed for the selected indicator parameters (Fig. 4), which could be related to the 


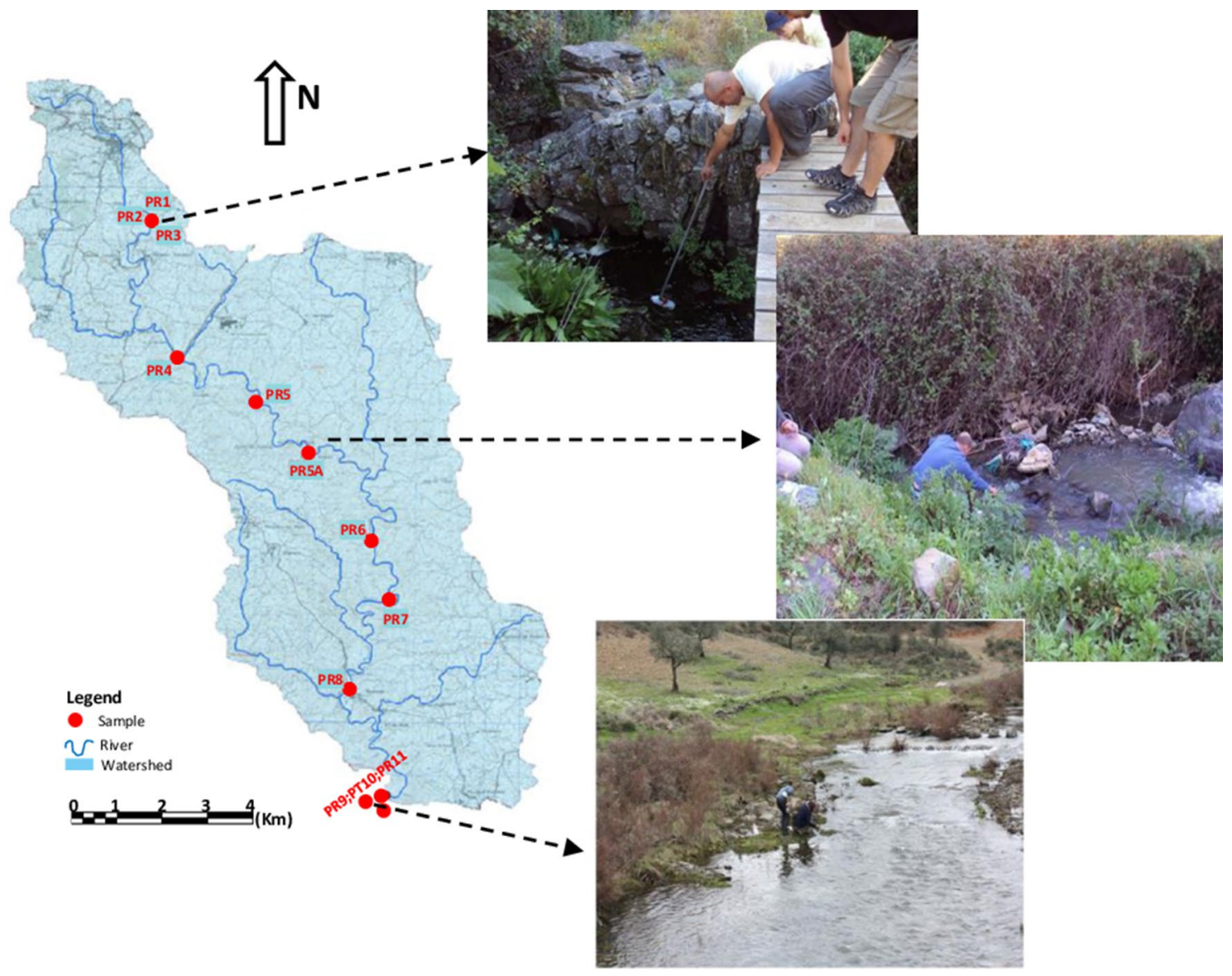

Fig. 2 Overview of the study area and the Freixada River's gauging stations

Table 1 Laboratory parameter protocol for water quality determination

\begin{tabular}{ll}
\hline Parameter & Analytical methods \\
\hline $\mathrm{MP}$ & PAFQ09 based on norm SMEWW 2540 D \\
$\mathrm{BOD}_{5}$ & Manometric method \\
$\mathrm{DO}$ and COD & Volumetric precipitation \\
$\mathrm{N}_{\text {total }}$ & Computed \\
$\mathrm{P}_{\text {total }}$ & Molecular absorption spectrometry \\
\hline
\end{tabular}

addition of diffuse contributions associated with agriculture seasonality and river flow rate reduction.

To the model calibration, the QUAL2Kw software offers manual or auto-calibration, using an internal genetic algorithm which calibrates the model automatically based on several specified stoichiometric rates and constants [32]. Calibration is a process through which an optimized fitting between observed and predicted values was obtained. In the case of the study, auto-calibration was used for January, April and June campaigns.
A general analysis allows saying that the calibration results for the various parameters were acceptable. In future work, field flow rates and kinetic coefficient values are keen covariates for calibration improvement and, therefore, the enhancement of the QUAL2Kw fitted model quality.

\subsection{Dissolved oxygen calibration}

Dissolved oxygen calibration for the analyzed temporal periods varies according to the received influences along the river course (Fig. 5). The best calibration was obtained in the rainy season (January) due to higher flow rates. On average, it is possible to conclude that the Freixada River shows normal oxygenation content and satisfactory surface water quality.

\subsection{Biochemical oxygen demand $\left(\mathrm{BOD}_{5}\right)$ calibration}

The results of the biochemical oxygen demand $\left(\mathrm{BOD}_{5}\right)$ calibration show high temporal variability (Fig. 6). Whereas in the first campaign (January), the observed 


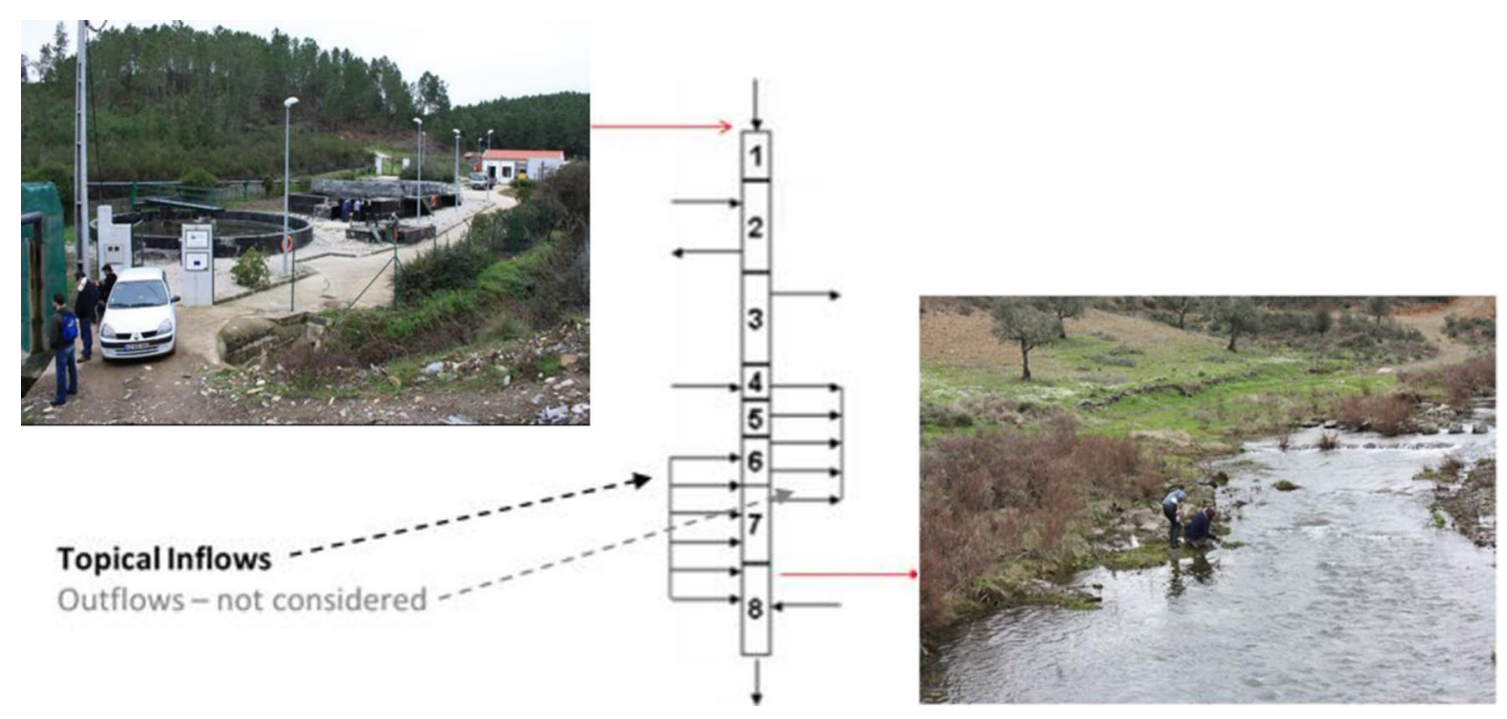

Fig. 3 River segmentation

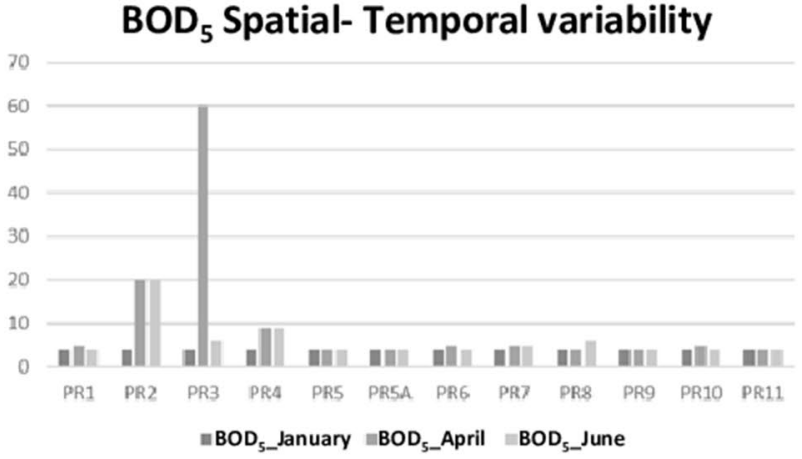

(a)

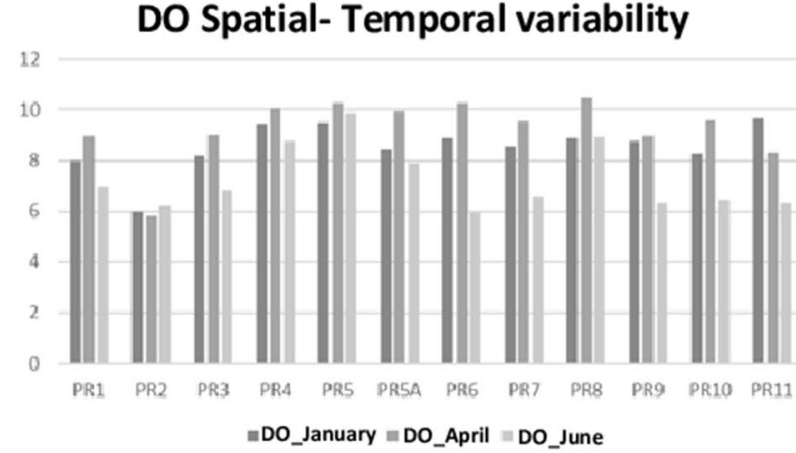

(b)

Microbiological parameters SpatialTemporal variability

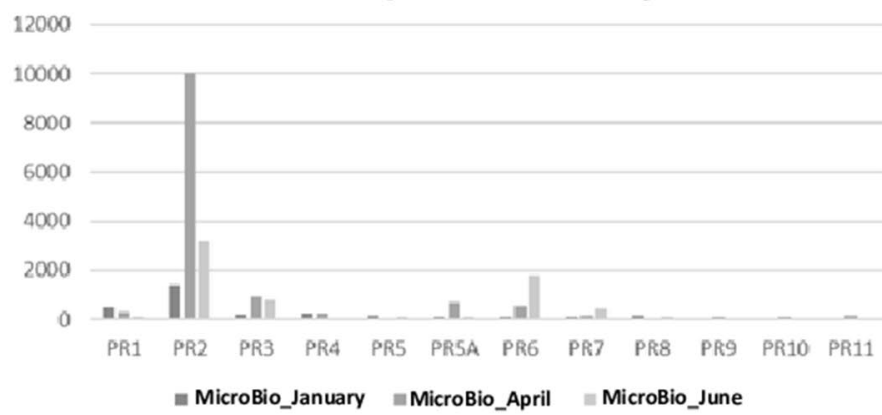

(c)

Fig. 4 Spatiotemporal variability for: $\mathbf{a} \mathrm{BOD}_{5}$; b dissolved oxygen (DO) and $\mathbf{c}$ microbiological parameters

values fairly agree with the predicted ones, for the campaigns of April and June 2010, a few discrepancies can be kept close to the wastewater plant discharge
(Fig. 6). The decreasing river flow rate, associated with deficient water treatment, may explain the observed variability. However, the Freixada River shows a good 
self-depuration and no impact will be expected in the Pracana reservoir.

\subsection{Microbiological parameters calibration}

In relation to microbiological parameters, the calibration results are acceptable and in concordance show a constant trend along the hydrological year (Fig. 7). The content of microbiological parameters, detected close to the Pracana reservoir, is within the admissible ones, for good water quality and stressing a good level of selfdepuration along the river.

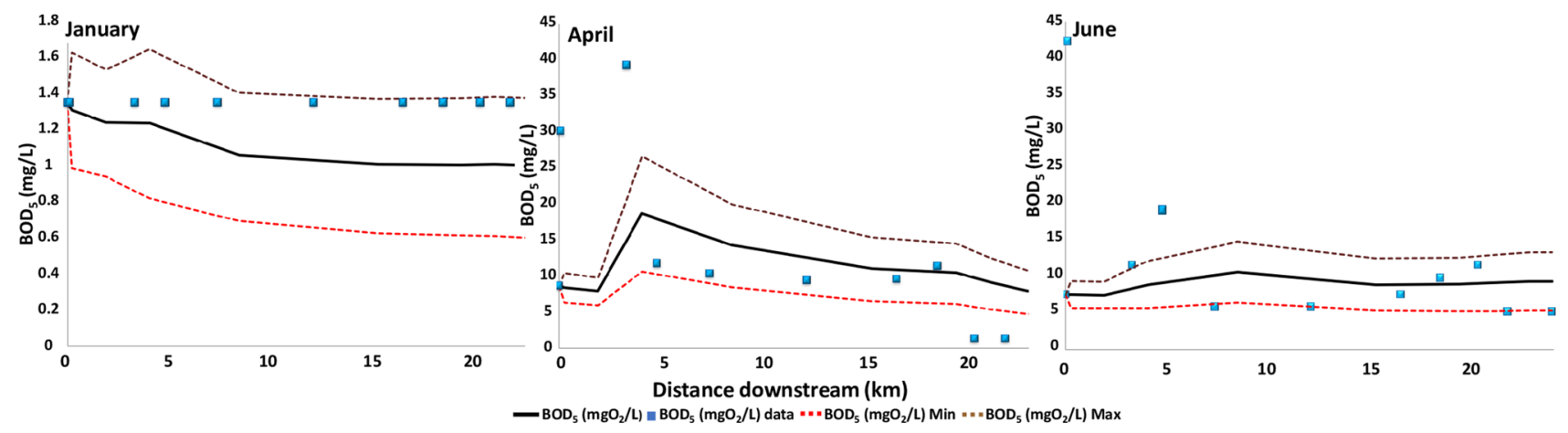

Fig. 5 Seasonal DO calibration: ———fitted curve; min values; -------- max values; $\square$ Observations

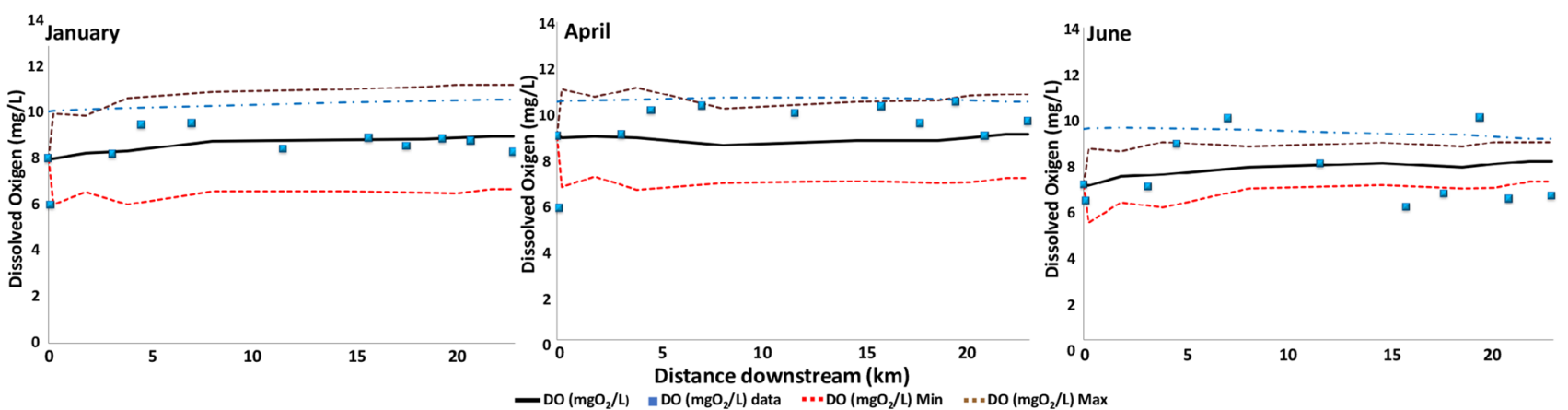

Fig. 6 Seasonal $\mathrm{BOD}_{5}$ calibration: _—— fitted curve; ---------- min values; -------- max values; $\square$ Observations

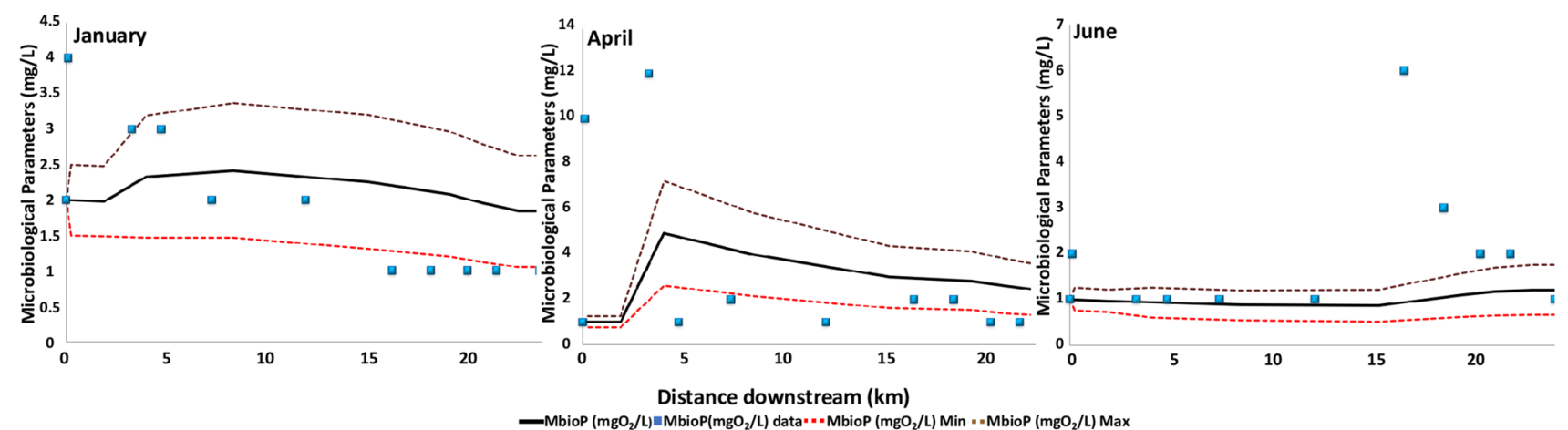

Fig. 7 Seasonal microbiological parameter calibration: fitted curve; min values; Observations 


\section{Conclusions}

1. The entrance into force of the Directive 2000/60/EC of the European Parliament for technical specifications for chemical analysis and monitoring of water status has made mandatory the development of management strategy and decision support tools, for water in all European countries.

2. The numerous environmental pressures and changes resulting mainly from human activity to which surface waters are subjected coupled with water pollution problems have led to the need to build a surface water quality indicator system.

3. The Pracana River water quality monitoring was carried out over three sampling campaigns aiming to assess the spatiotemporal evolution and its impact on the Pracana reservoir, which is overlapping a protected area.

4. The modeling system used was the QUAL2Kw that was able to represent with skill and flexibility the experimental physical, chemical and hydraulic aspects observed in this study. The simulated results are consistent with field observations and demonstrate that the model has been calibrated. QUAL2Kw accurately demonstrates the dynamic development of the chosen indicator parameters $\left(\mathrm{DO}, \mathrm{CBO}_{5}\right.$ and microbiological parameters). QUAL2Kw can reasonably be used in small watersheds for the assessment of the effects of different model fittings in an aquatic environment. This mathematical model requires simple input parameters and offers a full framework for the simulation of surface water quality, especially in places with scarce monitoring data. The model is also flexible as it can be used without knowing all the involved parameters as assuming default values.

5. The obtained results in different simulated scenarios show that the stream has a satisfactory water quality for multiple uses and does not contribute to the water of the Pracana reservoir quality. Nevertheless, due to the values of $\mathrm{BOD}_{5}$, water is not fit for human consumption.

6. The simulation results are consistent with field observations and demonstrate that the model has been acceptably calibrated. The results obtained in different simulated scenarios tell us that the stream flow shows a quite satisfactory water quality for multiple uses and should not be an issue for the Pracana reservoir quality. However, due to the values of $\mathrm{BOD}_{5}$, water is not fit for human consumption. Lastly, before the release of the effluent into the stream, the treatment should be improved.
7. Water may become the most strategic resource in many parts of the world within the next decades. The identification of critical control water quality parameters and their concentrations provides great opportunities for improving water sustainability in the future. Therefore, regularly monitoring and evaluating the quality of river water are required for integrated management of these water resources.

Acknowledgements The authors acknowledge the financial and coordination support provided by Águas do Centro Enterprise and by the Institute of Earth Sciences (ICT), under contracts UID/ GEO/04683/2013 with FCT (the Portuguese Science and Technology Foundation).

Author contributions All authors contributed extensively to the work presented in the paper. Albuquerque M.T.D., Antunes I.M.H.R. and N.P. Oliveira were involved in fieldwork design, sampling and laboratory analysis, and G. Pelletier and N.P. Oliveira conducted the simulation procedure and model calibration. All were involved in results evaluation and discussion. Finally, Albuquerque M.T.D wrote the manuscript with the contribution and editing of all the co-authors.

\section{Compliance with ethical standards}

Conflict of interest The authors declare that they have no competing interests.

\section{References}

1. Gonzalo C, Camargo JA (2013) The impact of an industrial effluent on the water quality, submersed macrophytes and benthic macroinvertebrates in a dammed river of central Spain. Chemosphere 93(6):1117-1124. https://doi.org/10.1016/j.chemo sphere.2013.06.032

2. Li D, Sharp JO, Drewes JE (2016) Influence of wastewater discharge on the metabolic potential of the microbiological community in river sediments. Microb Ecol 71:78-86. https://doi. org/10.1007/s00248-015-0680-x

3. Aubertheau E, Stalder T, Mondamert L, Ploy MC, Dagot C, Labanowski J (2017) Impact of wastewater treatment plant discharge on the contamination of river biofilms by pharmaceuticals and antibiotic resistance. Sci Total Environ 579:1387-1398. https://doi.org/10.1016/j.scitotenv.2016.11.136

4. Hilario Garcia AL, Matzenbacher CA, Santos MS, Prado L, Picada JN, Premoli SM, Correa DS, Niekraszewicz L, Dias JF, Grivicich I, da Silva J (2017) Genotoxicity induced by water and sediment samples from a river under the influence of brewery effluent. Chemosphere 169:239-248. https://doi.org/10.1016/j.chemo sphere.2016.11.081

5. Zafar S, Kahan A, Ullah H, Khan MS, Khan I, Hammed A, Rehman SU, Yasmeen G (2017) Risk assessment of Giardia from a full scale MBR sewage treatment plant caused by membrane integrity failure. J Environ Sci 30:252-258

6. Xiao S, Hu S, Zhang Y, Zhao X, Pan W (2018) Influence of sewage treatment plant effluent discharge into multipurpose river on its water quality: a quantitative health risk assessment of Cryptosporidium and Giardia. Environ Pollut 233:797-805 
7. Lecomte KL, García MG, Fórmica SM, Depetris PJ (2009) Influence of geomorphological variables on mountainous stream water chemistry (Sierras Pampeanas de Córdoba, Argentina). Geomorphology 110:195-202. https://doi.org/10.1016/j.geomo rph.2009.04.016

8. Sullivan CA, Reidy Liermann C, Davies PM (2010) Global threats to human water security and river biodiversity. Nature 467:555561. https://doi.org/10.1038/nature09440

9. Zhou T, Wu JG, Peng SL (2012) Assessing the effects of landscape pattern on river water quality at multiple scales: a case study of the Dongjiang River watershed, China. Ecol Indic 23:166-175. https://doi.org/10.1016/j.ecolind.2012.03.013

10. Antunes IMHR, Albuquerque MTD, Seco MFM (2016) Avaliação da vulnerabilidade especial na água subterrânea. Las aguas subterráneas y la planificación hidrológica. Iberian Conference, Madrid, Spain. AIH-GE, SIBN: 978-84-938046-5-7

11. Antunes IMHR, Albuquerque MTD, Oliveira SF, Sánz GL (2018) Predictive scenarios for surface water quality simulationa watershed case study. CATENA 170:283-289. https://doi. org/10.1016/j.catena.2018.06.021

12. Henderson-Sellers B (1991) Water quality modeling: decision support techniques for lakes and reservoirs. CRC Press, London

13. DiGiano F, Grayman WM (2014) Can we better protect vulnerable water supplies? J Am Water Works Assoc 106:28. https:// doi.org/10.5942/jawwa.2014.106.0067

14. Tillaart SPM, Booij MJ, Krol MS (2013) Impact of uncertainties in discharge determination on the parameter estimation and performance of a hydrological model. J Hydrol 44(3):454-466. https://doi.org/10.2166/nh.2012.147

15. Whitehead PG, Futter MN, Comber S, Butterfield D, Pope L, Willows R, Burgess C (2015) Modelling impacts of seasonal wastewater treatment plant effluent permits and biosolid substitution for phosphorus management in catchments and river systems. J Hydrol 46(3):313-324. https://doi.org/10.2166/nh.2014.100

16. Khwairakpam E, Khosa R, Gosain A et al (2019) Monitoring and modelling water quality of Loktak Lake catchment. SN Appl Sci 1:491. https://doi.org/10.1007/s42452-019-0517-1

17. Farhadian M, Bozorg-Haddad O, Pazoki M, Loáiciga HA (2019) Minimal adverse impact of discharging polluted effluents to rivers with selective locations. Sust Cities Soc 46:101394. https:// doi.org/10.1016/j.scs.2018.12.022

18. Basri SM, Sera K (2017) Current mercury exposure from artisanal and small-scale gold mining in Bombana, Southeast Sulawesi, Indonesia-future significant health risks. Toxics 5(1):1-7. https ://doi.org/10.3390/toxics5010007

19. Yakubu $\mathrm{OH}$ (2017) Pharmaceutical wastewater effluent-source of contaminants of emerging concern: phytotoxicity of metronidazole to soybean (Glycine max). Toxics 5(2):1-10. https://doi. org/10.3390/toxics5020010

20. Rodrigo M (2017) The WFD implementation in the European member states. Water Resour Manag 31(10):3043-3060. https ://doi.org/10.1007/s11269-017-1723-5

21. Sousa JCG, Ribeiro AR, Barbosa MO, Pereira FR, Silva AMT (2018) A review on environmental monitoring of water organic pollutants identified by EU guidelines. J Hazard Mater 344:146-162. https://doi.org/10.1016/j.jhazmat.2017.09.058
22. OECD (2011) Development in Eastern Europe and the South Caucasus: Armenia, Azerbaijan, Georgia, Republic of Moldova and Ukraine. OECD Publishing, Paris. https://doi.org/10.1787/97892 64113039-en

23. Delhomme O, Rib E, Millet M (2008) Polycyclic aromatic hydrocarbons analyzed in rainwater collected on two sites in East France (Strasbourg and Erstein). Polycycl Aromat Compd 28:4-5

24. Tiedeken EJ, Tahar A, McHugh B, Rowan NJ (2017) Monitoring, sources, receptors, and control measures for three European Union watch list substances of emerging concern in receiving waters-a 20 year systematic review. Sci Total Environ 574:11401163. https://doi.org/10.1016/j.scitotenv.2016.09.084

25. Vystavna Y, Frkova Z, Celle-Jeanton H, Diadin D, Huneau F, Steinmann M, Crini N, Loup C (2018) Priority substances and emerging pollutants in urban rivers in Ukraine: occurrence, fluxes and loading to transboundary European Union watersheds. Sci Total Environ 637-638:1358-1362. https://doi.org/10.1016/j.scito tenv.2018.05.095

26. Henderson-Sellers B (1991) Water quality modeling: decision support techniques for lakes and reservoirs, vol 4. CRC Press, Boston, $\mathrm{p} 344$

27. Lin CE, Kao CM, Jou CJ, Lai YC, Wu CY, Liang SH (2010) Preliminary identification of watershed management strategies for the Houjing River in Taiwan. Water Sci Technol 62(7):1667-1675. https://doi.org/10.2166/wst.2010.460

28. Grabiç J, Bezdan A, Benka P, Salvai A (2011) Spreading and transformation of nutrients in the Reacg of the Becej-Bogojeco Canal, Serbia. Carparth J Earth Environ Sci 6(1):277-284

29. Jeznach LC, Jones C, Matthews T, Tobiason JE, Ahlfeld DP (2016) A framework for modeling contaminant impacts on reservoir water quality. J Hydrol 537:322-333. https://doi.org/10.1016/j. jhydrol.2016.03.041

30. Sharma D, Kansal A (2013) Assessment of river quality models: a review. Rev Environ Sci Biotechnol 12:285-311. https://doi. org/10.1007/s11157-012-9285

31. Fan C, Ko CH, Wang WS (2009) An innovative modeling approach using Qual2K and HEC-RAS integration to assess the impact of tidal effect on river water quality simulation. J Environ Manag 90(5):1824-1832. https://doi.org/10.1016/j.jenvm an.2008.11.011

32. Pelletier GJ, Chapra SC, Tao H (2006) QUAL2 Kw-a framework for modelling water quality in streams and rivers using a genetic algorithm for calibration. Environ Model Soft 21(3):419-425. https://doi.org/10.1016/j.envsoft.2005.07.002

33. Abderrezzak KEK, Ata R, Zaoui F (2015) One-dimensional numerical modelling of solute transport in streams: the role of longitudinal dispersion coefficient. J Hydrol 527:978-989. https://doi. org/10.1016/j.jhydrol.2015.05.061

34. Xiaobo F, Jianying Z, Yingxu C, Xiangyang X (2008) QUAL2K model used in the water quality assessment of Qiantang River, China. Water Environ Res 80(11):2125-2133

Publisher's Note Springer Nature remains neutral with regard to jurisdictional claims in published maps and institutional affiliations. 